\title{
POST TERM PREGNANCY; EFFICACY OF PGE2 IN INDUCTION OF LABOUR
}

1. MBBS, MCPS, FCPS, Assistant Professor, Independent University Hospital, Faisalabad.

2. MBBS, FCPS,

Assistant professor, Independent University Hospital, Faisalabad.

3. MBBS, FCPS, Assistant Professor Independent University Hospital, Faisalabad.

4. MBBS, FCPS

Assistant professor, Independent University Hospital, Faisalabad.

Correspondence Address:

Dr. Uzma Shahzad

Assistant Professor,

Independent University Hospital,

Faisalabad.

Uzmas041@gmail.com

Article received on:

19/12/2016

Accepted for publication:

25/02/2017

Received after proof reading: $06 / 04 / 2017$

\section{Dr. Uzma Shahzad1', Dr. Uzma Manzoor ${ }^{2}$, Dr. Nadia Awais ${ }^{3}$, Dr. Tasneem Azher ${ }^{4}$}

\begin{abstract}
Post term pregnancy is used to describe pregnancy that continues for 294 days or more following the first day of last menstrual period. Post term pregnancy has been considered to occur in $10-20 \%$ of all pregnancies. PGE2 have been used vaginally for induction of labour for the last two decades. Routine induction of labour after 41 weeks gestation appears to reduce perinatal mortality. Objectives: The study was done to: 1) To calculate the induction - delivery time with prostaglandins E2 in prolonged pregnancy. 2) To find frequency of normal vaginal delivery versus caesarean section after induction with prostaglandins E2. Study design: It was descriptive study. Setting: It was study of fifty patients carried out in Gynae unit 1 Allied Hospital Faisalabad. Period: 03 March 2005 to 02 March 2006. Subjects: Inclusion Criteria: 1) All patients with prolonged pregnancy of more than forty two weeks were included. 2-Only singleton pregnancies were included. Exclusion criteria: 1-Patients who had previous caesarean section were excluded from the study. 2) Patients who had associated obstetric condition that modify the mode of delivery were excluded. Data collection procedure: Detailed history and examination was carried out with availability of dating ultrasound to ascertain dates. Bishop score assessed. Tests of foetal well being carried out. After informed consent induction of labour carried out with prostin E2, and effect studied on induction - onset and delivery intervals and mode of delivery. Results: Induction onset interval was 3.5 hours in Primigravida, was 2.8 hours in group 2(G2 \& G3) and 2.0 hours in group 3(G4 \& more). Induction delivery interval was 18 hours in group 1 , 14 hours in group 2 and $10-12$ hours in group 3 . Mean percentage of normal vaginal delivery was $78.5 \%$ in all groups. Forceps delivery was $5.6 \%$ and caesarean section was $15.7 \%$. Number of patients successfully induced was $84.2 \%$ Conclusion: The study confirmed the efficacy of PGE2 tablets in achieving cervical ripening. It was also seen to decrease induction delivery interval more so in multigravida.
\end{abstract}

Key words: $\quad$ Post term pregnancy, Induction of labour, PGE 2 vaginal tablets.

Article Citation: Shahzad U, Manzoor U, Awais N, Azher T. Post term pregnancy; efficacy of PGE2 in induction of labour. Professional Med J 2017;24(4):500-506.

DOI: $10.17957 / T P M J / 17.3381$

\section{INTRODUCTION}

Post term, postdates, prolonged and post mature are all terms officially accepted by world health organization to describe pregnancy that continues for 294 days or more following the first day of last menstrual period (LMP) assuming valid dates and a regular 28 days cycle. ${ }^{1}$

Prostaglandin E2 and F2a evoke myometrial contractions in the woman at anyage of pregnancy. Within the uterus amnion and chorion produce PGE2. Where as in decidua both PGE2 \& PGF $2 a$ are synthesized. During last two trimesters of pregnancy administration of either PGE2 \& PGF2 a cause strong uterine contractions and can induce delivery of foetus. ${ }^{2}$ Post term pregnancy has been considered to occur in $10-20 \%$ of all pregnancies. $^{3}$

Woman who have one previous prolonged pregnancy and those who have had two prolonged pregnancies have a $30 \%$ and $40 \%$ chance respectively of another prolonged pregnancy. ${ }^{4}$ PGE 2 have been used vaginally for induction of labour for the last two decades. Over the last decade induction of labour has become one of the most common procedures performed in delivery room services. ${ }^{6}$ Induction of labour is increasing by approximately $25 \%$ in United States ${ }^{7}$ Routine induction of labour after 41 weeks gestation appears to reduce perinatal mortality. ${ }^{8,9}$ 
Perinatal mortality increases after 42 weeks, doubles at 43 weeks, quintuples at 44 weeks of gestation. ${ }^{10}$ The main risk to mother is that of prolonged labor and operative delivery. ${ }^{11}$ With modern use of ultrasound to determine gestational age and to detect intra uterine growth retardation (IUGR) few mother exceed 42 weeks. ${ }^{12}$ There is definitive risk associated with post maturity. We must be sure that any measures we take to avoid it are not themselves more dangerous than post maturity. ${ }^{13}$

\section{MATERIAL AND METHODS}

\section{Setting}

The study was conducted in the department of obstetrics and gynecology of Allied Hospital, Faisalabad, which is a tertiary care unit, attached with the teaching institute Punjab Medical College.

\section{Duration of study}

The study was carried out in one year period from 03 march 2005 to 02 march 2006

\section{Sample Size}

The study included all cases who meet the inclusion criteria to a minimum of about 50 cases

\section{Inclusion criteria}

1. All patients with prolonged pregnancy of more than forty two week were included.

2. Only singleton pregnancies were included.

\section{Exclusion criteria}

1. Patients who had previous caesarean section were excluded from the study.

2. Patients who had associated obstetric condition that modify the mode of delivery like placenta previa, cephalopelvic disproportion were excluded.

\section{Study design}

It was descriptive study.

\section{Data collection procedure}

All the patients admitted with diagnosis of prolonged pregnancy were evaluated as;

\section{History}

Detailed history of the patient was taken including the exact date of last menstrual period and cycle length. Obstetric history was taken. Patient was enquired about any ultrasound done in $1^{\text {st }}$ trimester, onset of quickening, to rule out mistaken dates.

\section{Examination}

The detailed examination was carried out abdominal examination was carried out including height, symphysio fundal height, lie, amount of liquor, presenting part and its engagement, foetal heart sounds, any uterine contractions. Bishop score was assessed.

Tests of wellbeing were carried out including movement chart, non stress test, contraction stress test; biophysical profile. Routine investigations were carried out. Induction was carried out with vaginal tablet prostin E2 was repeated as required. Efficacy of prostin E2 was studied with regard to induction-onset and induction-delivery interval and mode of delivery.

Caesarean sections were carried out for Failed induction, Failure to progress, Foetal distress.

\section{Data analysis}

Data will be entered into SPSS 10 and analyzed accordingly

\section{Test of Significance}

Since outcome of study will be qualitative, so chisquare will be used

\section{RESULTS}

During study period of one year, there were total 50 post term patients, who were induced with prostin E2. They were divided into three groups for purpose of study according to their gravidity.

- Group 1-primigravida -29 patients 58\%

- Group 2- Gravida 2 \&3 - 15 patients 30\%

- Group 3- Gravida $4 \& 5$ or more -6 patients $12 \%$

All groups showed an increase in the bishop score after insertion of PGE2 tablet. The effects of various factors like age, parity, booking, and bishop score on mode of delivery were studied. 
The common causes for caesarean section were also identified.

In the present study prostaglandins E2 was used to induce labour in 50 patients in dose of $3 \mathrm{mg}$ which was repeated at six hour intervals upto a maximum dose of $9 \mathrm{mg}$. The effect of prostaglandins on the cervix was assessed by measuring the improvement in the bishop score and on the uterus in the form of contractions. The age distribution covered the reproductive period of female life span eleven (22\%) were aged $<20$ years. Thirty four $(68 \%)$ were aged 21 30 years, while five (10\%) were aged $31-40$ years.

In the present study twenty (40\%) were booked patients and thirty (60\%) were unbooked.

Bishop score at induction was unfavorable (0-5) in majority forty seven (94\%) \& was in favorable range (6-14) in only three (6\%) patients. The induction onset and induction delivery interval were studied in different groups. They were influenced by parity and mean bishop score at induction, were more in Primigravida, than multi gravida. The induction onset interval was 3.5 hours in primigravida, was 2.8 hours in group 2 and 2.0 hours in group 3 . Induction - delivery interval was 18 hours in group 1, 14 hours in group 2 and 10-12 hours in group 3.

Majority of patients included in study responded to a single prostin tablet. Group requiring single prostin tablet were twenty six (52\%). Patients in which PGE2 was repeated once were twenty one $(42 \%)$ three tablets were required in only three (6\%) patients.

Mode of delivery was studied in different groups. In group 1 out of twenty nine patients twenty one (72.4\%) were delivered normally and three (10.3\%) patients had forceps delivery and five (17.2\%) had lower segment caesarean section. In group 2 out of fifteen patients twelve (80\%) patients were delivered vaginally one patient $(6.6 \%)$ had forceps delivery and two (13.3\%) were delivered by the lower segment caesarean section. In group 3, out of six patients, five $83.3 \%$ had normal vaginal and one (16.6\%) had lower segment caesarean section, none had instrumental delivery.

Mean percentage of normal vaginal delivery was $78.5 \%$ in all groups, Mean percentage of forceps delivery was 5.6 percent Mean percentage of caesarean section was 15.7 percent Number of patients successfully induced were twenty four $82.7 \%$ in group 1, were thirteen $86.6 \%$ in group 2 and five $83.3 \%$ in group 3 . Mean success rate in all groups were $84.2 \%$ Lower segment caesarean section were carried out for following indications

- Failure to progress 5

- Failed induction 2

- Foetal distress 2

Side effect were studied in all groups; most common were nausea and vomiting. Rare side effects were hyperstimulation, retained placenta, postpartum haemorrhage and bronchoconstriction.

The study confirmed the efficacy of prostaglandin vaginal tablets. These are safe and effective method of labour induction. The administration is simple and method is not attended with undue side effects. Outcome was studied as mean Apgar score at 1 min and 5 minutes. 8 babies were born with Apgar score $\leq 6$ at 1 minute, these later recovered and only 4 babies required admission in intensive care unit for meconium aspiration and apnoea. These were treated and discharge within a week. There were no perinatal losses.

\begin{tabular}{|l|c|c|}
\hline \multicolumn{1}{|c|}{ Age } & No of patients & Percentage \\
\hline$>20$ yrs & 11 & $22 \%$ \\
\hline $21-30$ yrs & 34 & $68 \%$ \\
\hline $31-40$ yrs & 05 & $10 \%$ \\
\hline
\end{tabular}

Table-l. Distribution of patients according to age Mean age : $25.04 \quad$ Ch- Square 39.760 Std. Deviation : $04.45 \quad$ P Value 0.001 **

Minimum age : 18.00

Maximum age: $36.00 * \star$ : Highly Significant

\begin{tabular}{|l|c|c|}
\hline \multicolumn{1}{|c|}{ Variables } & No. of Patients & Percentage \\
\hline Booked & 20 & $40 \%$ \\
\hline Un. Booked & 30 & $60 \%$ \\
\hline Table-II. Distribution of patients according to booking \\
status
\end{tabular}




\begin{tabular}{|l|c|c|}
\hline \multicolumn{1}{|c|}{ Parity } & No of Patients & Percentage \\
\hline Group 1 Primigravida & 29 & $58 \%$ \\
\hline Group 2 Gravida 2 \& 3 & 15 & $30 \%$ \\
\hline Group 3 Gravida $\geq 4$ & 06 & $12 \%$ \\
\hline
\end{tabular}

Table-III. Distribution of patients according to parity

\begin{tabular}{|l|c|c|}
\hline \multicolumn{1}{|c|}{ Variables } & No to Patients & Percentage \\
\hline Unfavorable (0-5) & 47 & $94 \%$ \\
\hline Favorable (6-14) & 3 & $6 \%$ \\
\hline
\end{tabular}

Table-IV. Distribution of patients according to Bishop Score at induction

Mean Bishop Score : 3.10

Chi-Square 13.00

Std. Deviation : 1.59 P Value 0.043*

Minimum Bishop Score : 0.00

Maximum Bishop Score : 6.00

* : Significant

\section{Variables}

Group 1 Primigravida

Group 2 Gravida 2 \& 3

Group 3 Gravida 4 \& 5

Table-V. Distribution of patients according to parity in relation to induction onset intervals

Chi - Square 69.379

$\mathrm{P}$ Value $0.001^{* *}$

$\star \star$ : Highly Significant

\begin{tabular}{l|c|}
\hline \multicolumn{1}{|c|}{ Variables } & Induction delivery interval \\
\hline Group 1 Primigravida & 3.5 Hours \\
\hline Group 2 Gravida $2 \& 3$ & 2.8 Hours \\
\hline $\begin{array}{c}\text { Group } 3 \text { Gravida } 4 \text { \& } 5 \\
\text { Table-VI. Distribution of patients according to parity } \\
\text { in relation to induction delivery intervals }\end{array}$ \\
$\begin{array}{l}\text { Chi - Square } 160.312 \\
\text { P Value } 0.008^{* *} \\
\text { ** : Highly Significant }\end{array}$
\end{tabular}

\begin{tabular}{|l|c|c|}
\hline \multicolumn{1}{|c|}{ Parity } & No of Patients & Percentage \\
\hline One tablet & 26 & $52 \%$ \\
\hline Two tablet & 21 & $42 \%$ \\
\hline Three tablet & 3 & $06 \%$ \\
\hline
\end{tabular}

Table-VII. Distribution of patients according to number of prostaglandins tablets required

Mean tablets : 1.54

Ch - Square 17.56

Std. Deviation : 0.61

$P$ Value $0.000^{* *}$

** : Highly Significant

\begin{tabular}{|c|c|c|c|c|}
\hline Age & Group 1 & Group 2 & Group 3 & Overall \\
\hline $\begin{array}{l}\text { Normal } \\
\text { Vaginal } \\
\text { delivery }\end{array}$ & $\begin{array}{c}21 \\
(42.0 \%)\end{array}$ & $\begin{array}{c}12 \\
(24.0 \%)\end{array}$ & $\begin{array}{c}05 \\
(10.0 \%)\end{array}$ & $\begin{array}{c}38 \\
(76.0 \%)\end{array}$ \\
\hline $\begin{array}{l}\text { Forceps } \\
\text { delivery }\end{array}$ & $\begin{array}{c}03 \\
(6.0 \%)\end{array}$ & $\begin{array}{c}01 \\
(2.0 \%)\end{array}$ & $\begin{array}{c}\text { No } \\
\text { delivery }\end{array}$ & $\begin{array}{c}4 \\
(8.0 \%)\end{array}$ \\
\hline L.S.C.S & $\begin{array}{c}5 \\
(10.0 \%)\end{array}$ & $\begin{array}{c}02 \\
(4.0 \%)\end{array}$ & $\begin{array}{c}01 \\
(2.0 \%)\end{array}$ & $\begin{array}{c}8 \\
(16.0 \%)\end{array}$ \\
\hline
\end{tabular}

Table-VIII. Distribution of patients according to parity

Chi- Square 15.736 in relation to mode of delivery

P Value $0.0490^{*}$

* : Significant

\begin{tabular}{|c|c|c|c|}
\hline Parity & $\begin{array}{c}\text { No of } \\
\text { Patients }\end{array}$ & $\begin{array}{c}\text { No of patients } \\
\text { successfully } \\
\text { induced }\end{array}$ & $\begin{array}{c}\text { Percentage } \\
\text { (successfully } \\
\text { induced) }\end{array}$ \\
\hline $\begin{array}{c}\text { Group 1 } \\
\text { Primigravida }\end{array}$ & 29 & 24 & $82.7 \%$ \\
\hline $\begin{array}{c}\text { Group 2 } \\
\text { Gravida 2 \& 3 }\end{array}$ & 15 & 13 & $86.6 \%$ \\
\hline $\begin{array}{c}\text { Group 3 } \\
\text { Gravida } \geq 4\end{array}$ & 06 & 05 & $83.3 \%$ \\
\hline
\end{tabular}

Table-IX. Distribution of patients according to parity in relation to successfully induced

\begin{tabular}{|c|c|c|}
\hline Parity & No of cases & Percentage \\
\hline Failure to progress & 4 & $50.0 \%$ \\
\hline Failed inductions & 02 & $25.0 \%$ \\
\hline Fetal distress & 02 & $25.0 \%$ \\
\hline Total Cases & 08 & $100.0 \%$ \\
\hline
\end{tabular}

Table-X. Distribution of patients according to indicators of lower segment caesarean section

\begin{tabular}{|c|c|c|c|c|}
\hline Age & Group 1 & Group 2 & Group 3 & Overall \\
\hline Nausea & $\begin{array}{c}07 \\
(14.0 \%)\end{array}$ & $\begin{array}{c}06 \\
(12.0 \%)\end{array}$ & $\begin{array}{c}03 \\
(06.0 \%)\end{array}$ & $\begin{array}{c}16 \\
(32.0 \%)\end{array}$ \\
\hline Vomiting & $\begin{array}{c}06 \\
(12.0 \%)\end{array}$ & $\begin{array}{c}03 \\
(06.0 \%)\end{array}$ & $\begin{array}{c}03 \\
(06.0 \%)\end{array}$ & $\begin{array}{c}12 \\
(24.0 \%)\end{array}$ \\
\hline $\begin{array}{l}\text { Hyper- } \\
\text { stimulation }\end{array}$ & & $\begin{array}{c}1 \\
(2.0 \%)\end{array}$ & & $\begin{array}{c}1 \\
(2.0 \%)\end{array}$ \\
\hline $\begin{array}{l}\text { Retained } \\
\text { Placenta }\end{array}$ & $\begin{array}{c}1 \\
(2.0 \%)\end{array}$ & & & $\begin{array}{c}1 \\
(2.0 \%)\end{array}$ \\
\hline $\begin{array}{l}\text { Post-partum } \\
\text { Hemorrhage }\end{array}$ & & & $\begin{array}{c}1 \\
(2.0 \%)\end{array}$ & $\begin{array}{c}1 \\
(2.0 \%)\end{array}$ \\
\hline $\begin{array}{l}\text { Broncho- } \\
\text { constriction }\end{array}$ & & & $\begin{array}{c}1 \\
(2.0 \%)\end{array}$ & $\begin{array}{c}1 \\
(2.0 \%)\end{array}$ \\
\hline \multicolumn{5}{|c|}{$\begin{array}{l}\text { Table-XI. Distribution of patients according to } \\
\text { incidence of side effects }\end{array}$} \\
\hline \multicolumn{5}{|c|}{$\begin{array}{l}\text { Chi - Square } 54.492 \\
\text { P Value } 0.094^{\text {NS }} \\
\text { NS : Non Significant }\end{array}$} \\
\hline
\end{tabular}




\section{DISCUSSION}

The management of prolonged pregnancy is controversial. ${ }^{14}$ All pregnancies judged to be 42 completed weeks should be managed as if abnormally prolonged ${ }^{15}$ Prolonged pregnancy is associated with significant risk of maternal morbidity and perinatal morbidity. ${ }^{16}$ Induction of labour is one of the most commonly performed obstetric procedure between 1990-1998 the rate of labour induction doubled from approximately $10-20 \% .{ }^{17}$ Prostaglandins are used for ripening of cervix, prostaglandins that have been the agent of choice for induction of labour is $\mathrm{PGE}_{2} \cdot{ }^{18}$

The results of this study confirm the efficacy of prostaglandins in ripening of cervix. It is an essential pre-requisite for induction of labour. All groups showed an increase in bishop score after insertion of PGE2 tablet. In present study indication for induction of labour was post term pregnancy. Mean success rate for labour induction was $84.2 \%$ and failure rate was $15.7 \%$. As regard the number of prostaglandin tablets required 52 percent required one tablet only $42 \%$ required two tablets and $6 \%$ required 3 tablets.

In study carried out in Hamdard University Hospital Karachi in department of obstetrics and gynaecology from Feb. 2002 to Jan 2003 showed comparable results. In that study post date pregnancy was the commonest indication for labour induction. In the study number of patients successfully induced were $91 \%$ and failed induction was $9 \% 35 \%$ of patients required only a single prostin tablet, $65 \%$ required two tablets and three tablets required in none. Mode of delivery was studied in patients induced with prostin E2.53\% had spontaneous vaginal delivery. $22 \%$ had instrumental delivery and $25 \%$ had caesarean section. The results are in contrast to present study where SVD spontaneous vaginal delivery was $78.5 \%$, instrumental delivery $5.6 \%$ and caesarean section rate $15.7 \%$. Indications for operative delivery were non progress of labour and Foetal distress. In present study indications for caesarean section were similar (failure to progress, failed induction, foetal distress) Adverse effects with PGE2 were vomiting, shivering, fever,
PPH were similar to side effects noted in present study..$^{19}$ Induction - onset and induction - delivery intervals were monitored.

Roztocil reported that the parity of patients influenced the interval between the onset of induction and the onset of uterine contractions, the duration of the first and second stage of labour and the consumption of prostin tablets. ${ }^{20}$ In a study carried out by Begum $A$ and Sohail $\mathrm{R}$ at Lahore showed induction- delivery interval of 13.4 hours in multigravida and 18.3 hours in primigravida. $^{2}$ The results are comparable to present study with induction delivery interval of 10-14 hours in G2, G3 and above and 18 hours in primigravida.

In another study by Syeda Batool Mazhar in 2000 showed induction delivery time interval of 15.7 hours with prostaglandinsE2 and lower segment caesarean section rate was $16 \% .{ }^{21}$ In a study carried out at Sobhraj hospital Karachi in the department of obstetrics and gyneacology form Sep 2000 to Sep 2001. Patients with prolonged pregnancy were induced by different methods. Common causes of lower segment caesarean section in induction group were foetal distress, failed induction, prolonged second stage and non progress of labour. ${ }^{22}$

Another study was conducted in labour ward of gynae unit 1 services hospital Lahore, for induction of labour from Jan $1^{\text {st }} 2000$ to Jan $1^{\text {st }}$ 2001. Induction of labour was carried out with prostaglandins E2 pessary with Bishop score of $\leq 6$ similarly in present study $94 \%$ of patients had unfavorable cervices with Bishop score of $0-5$ only $6 \%$ patients had Bishop score $\geq 6$. Indications for caesarean section were similar to present study. Caesarean section was performed for failed induction, failure to progress, foetal distress and standard obstetrical indication.

In study carried out at services hospital Lahore induction - to delivery interval was 21.2 hours in nullipara. In present study induction to delivery interval in nullipara was 18 hours and was 10-14 hours in Gravida 2, 3 and multipara. In 
study carried out at services hospital caesarean sections occurred in $11 \%$ of multipara and $26 \%$ of nullipara comparable to present study where caesarean section occurred in $14.9 \%$ of multipara (Gravida 2, 3 and more) and $17.2 \%$ of nullipara. ${ }^{23}$

\section{CONCLUSION}

1. Prostaglandins vaginal tablets are a safe and effective method of induction.

2. The administration is simple and the method is not associated with undue side effect.

3. The study confirmed the efficacy of PGE2 tablets in achieving ripening.

4. It was also seen to decrease induction delivery interval, more so in multigravida.

Copyright(C 25 Feb, 2017.

\section{REFERENCES}

1. Crowely P. Prolonged pregnancy. In: Chamberlain G, Steer PJ, editors. Turnbulls's obstetrics. $3^{\text {rd }}$ edi. Harcourt publisher's limited London 2001; 521-32.

2. Begum A, Sohail S. Induction of labour with prostaglandin E2 Vaginal tablets. Prof Med J 1996; 3:201-6.

3. Ekman G, Persson PH, Ulmsten ULF. Induction of labour in post term pregnant women. Int $\mathrm{J}$ Gynaecol Obstet 1986; 24:47-52.

4. Bakketeig L, Bergsjo P. Post term pregnancy magnitude of problem. In: chalmers I, Enkin M, Keirse. KJNC, editors, effective care in pregnancy and child birth. Oxford University press 1989; 765-75.

5. Iqbal S. Management of prolonged pregnancy JCPSP May 2004; 14(05).

6. Yeast JD, John A, Poskin M. Inductions of labour and the relationship to caesarean delivery: $A$ review of 7001 consecutive induction. Am J Obstet Gynaecol 1999; 180:628-33.

7. Ramsey PS, Ramin KD, Ramin SM. Labour induction, current opinion Obstet and Gynaecol 2000; 12:463-73.

8. Huang DY, Usher RH, Kramer MS, Yang H, Morin L, Fretts R. Determination of unexplained antepartum foetal deaths. Obstet Gynaecol 2000; 95:215-21.

9. Rhodes JC, Schoendorf KC, parker JD, contribution of excess weight gain during pregnancy and macrosomia to caesarean delivery rate, 1990-2000: paediatrics 2003; 111:1181-5.

10. Ahn MO, phelan JP. Epidemiologic aspects of the postdate pregnancy. Clin Obstet Gynaecol 1989; 32:228-33.

11. Chua S, Arulkumaran S. Prolonged pregnancy. In: David K, James PJ, Steer CP. High risk pregnancy management options with normal value in pregnancy. $2^{\text {nd }}$ ed Harcourt publishers limited London 1999; 1057-69.

12. Cardozo L,Fysh J, Pearce JM. Prolonged pregnancy the management debate. Br Med J 1986; 293:1050-62.

13. Macafee $\mathrm{CHG}$, Livingstone GB. Studies in prolonged pregnancy, part IV clinical assessment. $\mathrm{Br} \mathrm{J}$ Obstet Gynaecol 2003; 110:77-87.

14. Weinstein D, Erza Y, Picard R, Furman M, Expectant management of post term patients; observations and outcome Matern Faetal Medical 1996; 5: 293-7.

15. In: Cunningham FG, Gant NF, Leveno KJ. Post term pregnancy. In: Cunningham SG, Gant NF, Larrye, Gilstrap III, Hauth JC editors Williams Obstetrics. $21^{\text {st }}$ edition. Mc Graw - Hil122 Medical Publishing Division New York, Chicago 2001; 729-74.

16. Campbell MK, Ostbye T, Irgens LM, post term birth: risk factors and outcomes in a 10 years cohort of Norwegian births Obstet Gynaecol 1997; 89: 543-8.

17. Zhang J, Yancery MK, Henderson CE, US national trends in Labour induction 1989-1998 J Report Medicine 2002; 47:120.

18. Birlain M. Comparison of low doses of misoprostol with the traditional use of oxytocin for effective cervical ripening and labour induction, Obstet Gynaecol 2001; 97.

19. Hassan AA. A comparison of misoprostol tablets and vaginal prostaglandin $E 2$ pessary in induction of labour at term. JCPSP 2005; 15(5): 284-7.

20. Roztocil A, Paral V, Jelinek J, Holubove Peresta K. Labour induction using extra amniotic administration of PGE2. Cesk Gynekol 1990; 55(3): 161-7.

21. Mazhar SB, Sarwar S, Mahmud S. Induction of Labour randomized trial comparing prostaglandin E 2 Pessary, Intra cervical foley catheter and extra amniotic saline infusion. J Surg Dec 2000; 19-20: 128.

22. Iqbal S. Management of prolonged pregnancy. JCPSP 2004; 14(5): 274-7.

23. Jalil G, Malik RM. Induction of Labour an Audit of indications and obstetrical outcome in a tertiary care hospital. Pak postgraduate Med J July - Sep 2003; 14(3): 116-120. 


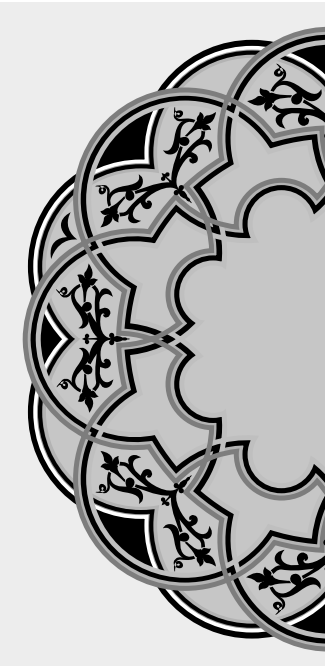

\section{"There are decades where nothing happens; and there are weeks where decades happen"}

Lenin

\begin{tabular}{|c|l|l|l|}
\hline \multicolumn{4}{|c|}{ AUTHORSHIP AND CONTRIBUTION DECLARATION } \\
\hline Sr. \# & \multicolumn{1}{|c|}{ Author-s Full Name } & \multicolumn{1}{c|}{ Contribution to the paper } & Author=s Signature \\
\hline 1 & Dr. Uzma Shahzad & $\begin{array}{l}\text { Main author of book and } \\
\text { research work } \\
\text { Help in data collection }\end{array}$ \\
\hline 2 & Dr. Uzma Manzoor & Help in writing paper & \\
3 & Dr. Nadia Awais & Help in writing paper & \\
4 & Dr. Tasneem Azher &
\end{tabular}

